\title{
A Correctional Plan for the Canadian Federal Penitentiary System \\ Tommy Bassio
}

Thave been incarcerated for the last quarter century and have lived the 1 changes that were enacted under the three previous Conservative federal governments (see Pelletier, 2017; Zinger, 2016). Changes that we all had hoped would come from the new Liberal government, have unfortunately not taken place (see Shook, this issue). I truly hope the people who are reading this right now take that seriously, and are motivated to speak out and help bring forward the change we all desperately need. You must write your federal Member of Parliament (for your riding), the Minister of Public Safety (Bill Blair), the Prime Minister (Justin Trudeau), and even a Senator or two for your province. Let them know that change must come and repeat the arguments in this writing, and/or add your own, but do write to them. If every prisoner in Canada writes these letters and convinces some family and friends to do so as well then change will have to come. Any letter you write to the Canadian Government in Ottawa is free (you do not need to pay stamps), so you can send a letter every week for free. It is time for all of us to make some noise and get the changes that we all so desperately need. Below, I discuss what, in my view, are the most profound and important changes that need to take place. Someone needs to pay attention before it is too late.

\section{THE SHIFT TOWARDS AN AMERICAN-STYLE SYSTEM}

I have watched this all play-out very slowly. I feel some changes that have been made are very un-Canadian and if ordinary Canadians actually understood this they would not tolerate it. The notion of rehabilitation has been replaced with the far-right leaning notion of punishment. The American 'tough on crime', 'lock them up and throw away the key' approach is the equivalent of sweeping the dirt under the rug. It does not fix the problem; it just moves it around. What have the Americans gained by their dungeons and 'tough on crime' approach? The result has been a super angry, distrustful, disenfranchised, poorer, and more desperate and dangerous society. Can we not say that the more freedom a country has and the more rights it affords to its citizens the better the society will look after their weakest members? Anyone who says we should lock people up and throw away the key is basically saying they are too ignorant, close-minded, hateful and scared to 
understand the merits of rehabilitation. Human rights and prisoners' rights go hand-in-hand. This shift that Canada has taken to the broken American style system (Webster and Doob, 2015) must stop. Many studies show that the harsher punishments do not reduce crime (see Mathiesen, 1990).

\section{LAWS ARE THERE TO PROTECT THE ACCUSED AND SOCIETY FROM A TOTALITARIAN STATE}

In the last quarter century, I have noticed a shift away from protecting the rights of the accused and/or convicted, as if eroding their rights gives victims greater standing. I can understand the need for the state to want to fight for the rights of victims, but that cannot and must not come at the cost of the rights of those in conflict with the law. This move undermines the whole justice system. Keep in mind as we continue down this dangerous slope, we will move closer to totalitarianism whereby citizens will be subjected to excessive state power. The Charter must take precedence and inform lawmaking in this country.

\section{MULTIPLE LIFE SENTENCES ARE UN-CANADIAN}

Life sentences are bad and cause way too much damage to the life of the prisoner (Hartman, 2013). That is why many progressive countries have removed the life sentence from their regime and with multiple chances for early parole, no matter the crime. Canada has made a great mistake by going in the other direction and sentencing people to multiple life sentences. Life25 was a bad enough trade-off when the death penalty was abolished in this country. Increasing parole eligibility beyond this offers little hope with respect to rehabilitation. Why would this prisoner with nothing more to lose not act out in the most violent and desperate way possible behind bars? It is inhumane to give such punishment, just as bad as the death penalty. A civilized society offers its people a chance to correct an error, a chance to improve one's life, a chance to rehabilitate. An emotional 18 year old can make a terrible mistake and because of a life sentence their whole life is ruined. People change, with multiple life sentences, the notion of rehabilitation has been eroded of its meaning. 


\section{PRISONER PAY NEVER ADJUSTED FOR INCREASED COST OF LIVING}

It is incredible to see how badly the federal penitentiary system has fallen. While outside of prisons staff wages rise with inflation, prisoner pay has stayed at rates established in the 1990s. Now CSC even cut our pay by a third, so we can pay further room and board costs (see Shook, 2018). About 20 years ago, CSC made a small change to try and help prisoners with their cost of living. They added $\$ 4.00$ extra on separate hygiene account so people could clean themselves properly. When given a choice of food or soap, people will choose food. So, the creation of a separate hygiene account where every pay an extra $\$ 4.00$ was given whether prisoners worked as the extra money could only be used to buy soap, toothpaste, shampoo and the like. This was a great move in progressive thought. Well, that was more than twenty years ago. What do you think $\$ 4.00$ every two weeks can buy for personal hygiene today? Deodorant costs $\$ 5.78$, toothpaste $\$ 3.85$, a toothbrush $\$ 4.25$, and so on. Basically, you make a choice, one time you buy deodorant, two weeks later shampoo, two weeks after that toothpaste, and if you need to buy some soap at $\$ 1.25$ a bar, that just means you may need to go for a month without deodorant. Is this how it should be? People choosing what they need to clean the most? This is shameful.

Prisoner pay is just as bad. It has not been raised since the 1990's (ibid). People who have no families and rely only on their pay inside can take up two years to buy a television for themselves to occupy their minds and keep them current with the world. It is beyond ridiculous. It is shameful. Basically, the only way around this is to sell drugs or steal and sell things from the prison kitchen, basically relying on the prison black market to make ends meet. Some people who never stole a thing in their lives are working in the kitchen so they can steal extra food, sell it and use the profits to purchase basic necessities. The only solution, and it would fix dozens of spin-off problems, would be to make a long overdue pay correction. The best way to do this would be to base our daily wage on the national average hourly minimum wage. When the national average minimum hourly wage is raised to meet cost of living and inflation, then the prisoners' daily pay follows. If the national average minimum hourly wage is $\$ 10.00$, then that should be our minimum daily wage. That is why my idea of mirroring the national average minimum wage makes the most sense. Most people in 
prison make $\$ 5.80$ a day, a very few make $\$ 6.90$ a day (the top wage), and far more make less than $\$ 5.80$ a day. From this, they remove about a third for room and board, then there is cable cost, committee costs, the Prisoner Welfare Fund, and so on. We are lucky to have $\$ 2.50$ from the original pay received. Then keep in mind that whatever we buy, we must pay taxes on that as well. So, money that does not go very far to begin with, goes nowhere once CSC tacks on the room and board tariff. This ridiculous notion of room and board needs to end and pay must go up to meet inflation and the cost of living. Otherwise, problems stemming from this will continue to persist.

\section{PAROLE OFFICERS ARE GIVEN TOO MUCH POWER}

I have watched over the last two decades as parole officers have been given dictator-level power over those they are meant to help on their journey to rehabilitation and reintegration. Let me use myself as a perfect example. I am serving a life-25 sentence for first degree murder. I have been in jail for a quarter century. I am trying to cascade to a minimum, so I can get a few ETAs (escorted temporary absences) under my belt and continue with my positive socio-correctional development when I pass parole. My SRS (security risk scale) pegs me as a minimum level prisoner. The three factors that determine if we get lower security level (i.e. escape risk, risk to public safety and institutional adjustment) are completely in the hands of our parole officers, with no real checks and balances. It is normal to assume that after this much time behind bars I should be at a minimum-security level, if not already at a halfway house, working on my slow and steady reintegration plan back into society. Instead, I am a medium-security level prisoner and seem to be stuck at this level. I have completed my correctional plan, and fully motivated to complete every program and hurdle they place in front of me. I am not considered a problem prisoner and cannot even remember the last time I had a conviction for a disciplinary offence. But that all means nothing. The true deciding points are the big three factors. So, let's look at the factors that determine this closer in my case.

Escape risk: In the last 25 years I have never escaped, tried to escape, nor do I have a history of ever had escaped, attempted to escape, or have I ever been illegally at large. So, one would logically assume that my escape risk would be at the lowest of the 3 levels - low. My parole officer has left 
me at moderate, meaning that according to her, I represent a moderate risk for escape. Ridiculous.

As for the second factor, risk to public safety, I feel that the first-degree murder of another human being is the most severe crime that can be committed, so nothing can be said about the severity of the crime. However, all people serving a sentence for their crime must have a logical conclusion, there has to be a point where someone says okay, you served enough time. The founding principles of CSC is rehabilitation, not punishment. In my case, the victim was a criminal associate of mine, not some innocent bystander. He was someone who was well versed in criminal standards and behaviours, and knowingly took a chance by breaking certain criminal foundation rules. Court records revealed that the victim was intentionally brought to a secure location to be killed with the intention of not endangering the public and innocent bystanders. Despite being locked away with other people with similar charges, I have never repeated my offence, never stabbed anyone, never used a weapon on anyone, and have not even had a fist fight in my last 25 years. One would assume that my risk to public safety would be low. Yet my parole officer, again without explanation, has decided that my level is moderate.

The third deciding factor is institutional adjustment. In the past, I openly admit that I did take part in certain subculture activities to make ends meet. I had bought pot off another prisoner at a lower price and sold it at a small profit just to have decent food to eat. I was in no way a violent prisoner and I never openly challenged the administration. I was basically an average convict who cut some corners to make life in prison more bearable. Again, this is something that the administration has claimed I have not done in more than three years. I am not a person of interest to the security department, and no prisoner, con or staff member considers me to be anything but polite, respectful, and trying to follow my correctional plan. Again, one would assume that my institutional adjustment rating would be low. My parole officer again surprises everyone with a rating of moderate.

The point that I was trying to make is this - when I asked her why, especially since all factors and indications point towards a lower rating, her answer is (which unfortunately is the ithe same answer that every parole officer in Canada gives): "I agree you are doing fantastic, however I want to see this positive change for a longer period of time". This is what I mean by too much power. No parole officer has the power of a judge, to convict 
someone, and sentence them to lengthy periods in prison, but that is exactly the power they wield. She wants me to stay in medium for now, basically pushing back my parole by five years (according to new legislation on lifers' paroles), effectively adding time to my sentence. Who gave them this power? I was sentenced to Life-25, not Life-32. I can understand if I spent my last 25 years stabbing and fighting, but that is not the case. Not in my case and hundreds of other cases that I have noticed the exact same thing, the exact same line being used on non-problematic, non-violent prisoners who have the curse of the life sentence. Why does a parole officer have the power to say, "I want to see if this positive change continues for two more years?" A person's file should stand on its own. Nobody should be given the arbitrary power to extend one's sentence in prison simply because they can. So, if someone calls her a dirty name, she can extract vengeance by keeping that person in jail. Humans make mistakes, they have egos and they should not have such power over other humans. This is a crime against democracy, a crime against humanity. This is a bully in the worst form imaginable.

\section{INSUFFICIENT HALFWAY HOUSE CAPACITY AND BUILDING SUPER-PRISONS}

Halfway house space continues to be insufficient. A halfway house is an essential block in a prisoner's rehabilitation plan. With so many waiting to go into halfway houses, it makes it hard to believe that the government wants prisoners to rehabilitate, especially when we witnessed hundreds of millions of dollars spent on transforming existing penitentiaries into super-prisons. Why does Canada need larger federal penitentiaries? I mean seriously, think about it.

A prisoner kept in a penitentiary costs taxpayers many times more than if kept in a halfway house. That is just the cost in dollars and cents, while the cost to society is immeasurable. More halfway house spaces must be built, and people with long sentences need to be quickly placed into them.

\section{CENTRAL FEEDING SYSTEM}

I believe that the central feeding system must stop. Prisoners are human beings and should be treated as such. The very name itself is insulting, like we are animals. Aside from this, the logic to abandon the current 
food delivery system is very simple. Central feeding systems remove the nutritional value of the food. The second strike against this system is the loss of food quality and taste. If the government wants us to eat cardboard, then that should be part of our sentence. At present, it is not, and being fed this fare is an added punishment. There have been many reports of people getting violently sick from the food (Harris, 2017). Another important consideration is that kitchen work and training provide prisoners with job experience and training. Some people in the past, when the kitchens actually made food, worked there as butchers, bakers, short order cooks, diet chefs, and many other positions that gave prisoners not only a sense of team work and accomplishment, but after years of training in these positions allowed them to get out and find very good jobs in the food industry.

\section{RETURN TO POLICIES AND PRACTICES THAT PLACE A STRONGER EMPHASIS ON REINTEGRATION INTO SOCIETY}

There should be stronger emphasis and training for prisoners who are on their way out. I have seen job training cancelled, along with special school programs and even basic job skills training come to an end over the years. This must change. More money must be put back into these types of programs. What are people who have been in penitentiaries for decades to do when they get out? At the very best - and I mean at the very, very best - we can expect them to be a drain on society. I will not even mention the very worst. We must give the necessary tools that prisoners need to get out and stay out. A violence prevention program will not have the same value to a prisoner as kitchen training program or programs teaching computer skills, marketing, business management, and the like. Having the means to provide for yourself is a first and necessary building block to achieving the stability necessary to live safely in the community.

\section{CONCLUSION}

The system is failing and we need immediate change. The human cost and cost to our society is too high. Any positive progressive change to society is always met with a great amount of hostility at first, but it is this very change that makes a great progressive country, a great progressive country. 
Changes to universal healthcare was met with great criticism at first, but today most cannot even believe that any other system can even exist. Homosexuality, abortion, freedom of religion, freedom of the press, the abolition of the death penalty, and the like were all changes that Canada fought to make more acceptable to our conscience. Today these matters are automatics, things that are acceptable, because any other way would be unacceptable.

How can anyone truly think everything is okay when our citizens are made to suffer so much and for no purpose? In the future it will be totally unacceptable to treat prisoners the way we are being treated today. The question is who will be the next Tommy Douglas? Who will be the first to speak out and start the change? I truly hope it is you the reader and that you are motivated to take action.

\section{REFERENCES}

Harris, Kathleen (2017) "\$5.41 per prisoner per day: bad food, small portions fueling prison tensions, federal watchdog finds", $C B C$ News - October 31. Retrieved from https://www.cbc.ca/news/politics/correctional-investigator-zinger-report-1.4379823

Hartman, Kenneth (2013) Too Cruel, Not Unusual Enough: An Anthology Published by the Other Death Penalty Project, Lancaster: The Steering Committee Press.

Pelletier, Josephine (2017) "Dispatches from Federally Sentenced Women", Journal of Prisoners on Prisons, 26(1\&2): 35-36.

Mathiesen, Thomas (1990) Prison on Trial, London: Sage.

Webster, Cheryl M. and Anthony N. Doob (2015) "US Punitiveness 'Canadian Style'? Cultural Values and Canadian Punishment Policy", Punishment \& Society, 17(3): 299-321.

Zinger, Ivan (2016) "Human Rights and Federal Corrections: A Commentary on a Decade of Tough on Crime Politics in Canada", Canadian Journal of Criminology and Criminal Justice, 58(4): 609-627.

\section{ABOUT THE AUTHOR}

Tommy Bassio is a federal prisoner who has served more than 25 years of his life sentence. He remains incarcerated even though he has no prison history of escape or violence behind bars. He is a prison organizer, reformer and activist. He is currently being held at medium-security at Archambault Institution. 